\title{
Prozatím nevyužitá šance: situační analýza v pedagogickém výzkumu
}

\author{
Jan Kalenda \\ Univerzita Tomáše Bati, Fakulta humanitních studií, Centrum výzkumu \\ Redakci zasláno 15. 2. 2016 / upravená verze obdržena 7. 8. 2016 / \\ k uveřejnění přijato 17. 8. 2016
}

\begin{abstract}
Abstrakt: Studie se zabývá možnostmi využití situační analýzy v pedagogickém výzkumu. I když je situační analýza novou metodou, významně se rozvíjející až v poslední dekádě, lze se s ní dnes setkat v široké škále společenských a humanitních věd. Přes tento úspěch napřič různými obory prozatím nedošlo $\mathrm{k}$ výraznému rozšiřrení situační analýzy do výzkumu edukačního/pedagogického, a to ani v zahraničí, ani v ČR. Tomu stále dominuje zakotvená teorie první generace nebo konstruktivisticky orientovaná zakotvená teorie. Studie na tento deficit reaguje tím, že představuje situační analýzu jako „balík teorie/metody“, přičemž demonstruje nejenom její ontologicko-epistemologická východiska ke studiu sociální/edukační reality a hlavní rozdíly oproti klasické zakotvené teorii, ale i principy používání tř́ klíčových nástrojů situační analýzy: (1) situačních map, (2) map sociálních světů a arén a (3) pozičních map. U všech tří nástrojů pak ukazuje jejich využití při zkoumání rozmanitých aspektů vzdělávání. $V$ rámci diskuse těchto aspektů studie upozorňuje na stěžejní výhody situační analýzy jako teoreticko-metodologického př́stupu ke studiu pedagogických jevů.
\end{abstract}

Klíčová slova: situační analýza, zakotvená teorie, kvalitativní výzkum, metodologie pedagogického výzkumu

Zakotvená teorie, původně sestavená Barneym Glaserem a Anselmem Straussem (1967) za účelem upřesnění a systematizace často intuitivních postupů kvalitativního výzkumu v sociologii 50 . a 60 . let, patří po téměř pěti dekádách od své formulace $\mathrm{k}$ jedné ze stěžejních výzkumných tradic např́íc společenskými vědami (viz např. Denzin \& Lincoln, 2005; Creswell, 2014). Podle autorského týmu Stephana Titschera (Titscher et al., 2000) se dokonce dvě ze tří publikovaných kvalitativních studií ve společenskovědních časopisech v 90. letech nějakým způsobem schovávaly pod tento „užitečný deštník“ (Haig, 1995). 


\section{Od zakotvené teorie k zakotveným teoriím}

Za svůj úspěch zakotvená teorie vděčí zejména vzniku své „systematické verze“ (Denzin, 2007), kterou vypracoval Anselm Strauss ve spolupráci s Juliett Corbin (Strauss \& Corbin, 1990, 1998) a jíž se dostalo překladu do celé řady světových jazyků, včetně češtiny v roce 1999 (Strauss \& Corbin, 1999). Autoři v ní využili centrálních konceptů ${ }^{1}$ Glasera a Strausse (1967) z 60. a 70. let. Přehledným a uceleným způsobem popsali základní techniky sběru, analýzy a prezentace kvalitativních dat, které lze široce aplikovat na př́pad různorodých společenskovědních jevů a budovat na jejich základě teorie zakotvené $\mathrm{v}$ datech či podložené daty.

Právě tato varianta zakotvené teorie se v 90. letech významným způsobem rozšiŕila mnoha obory a stala se nedílnou součástí arzenálu kvalitativních výzkumných postupů i v pedagogice a dalších badatelských polích o edukační realitě. ${ }^{2} 0$ tom svědčí $i$ to, že je dnes zakotvená teorie běžně uváděna mezi osvědčené výzkumné postupy jak v metodologicky orientované literatuře v zahraničí (viz např. Mertens, 2015), tak v Čechách a na Slovensku (Gavora, 2010; Šed'ová, 2005; Švaříček, 2006; Švaříček et al., 2007). ${ }^{3}$

Přes svou nespornou narůstající oblibu v pedagogice a dalších oborech se „systematická“ (Denzin, 2007), „objektivistická“ (Bryant, 2002), „klasická“ (Hallberg, 2006) či „straussovská“ (Redman-MacLaren \& Mills, 2015) zakotvená teorie „první generace autorü“ (Morse et al., 2009) stala okolo roku 2000 terčem rozsáhlé kritiky jak z řad teoretiků a epistemologů vědy, tak

1 Jednalo se zejména o dva koncepty: (1) neustálá srovnávací analýza, která spočívá v konstantní komparaci zjištění od jednotlivých informantů výzkumu s dosavadním sebraným materiálem a jeho další revizí a na ni navazujícím srovnání nových interpretací a kategorizací dat s těmi již existujícími; (2) kódovací paradigma, jež popisuje principy interpretace textových dat a jejich seskupování - tzv. otevřené, selektivní a osové či axiální kódování.

2 V textu používáme termíny edukační/pedagogický výzkum či edukační/pedagogická realita jako synonyma.

3 Jane Hood (2007, s. 151) uvádí výmluvnou statistiku, která dokumentuje expanzi zakotvené teorie skrze pole společenskovědních výzkumů. Zatímco v 80. letech bylo v databázi Academic Premier Search (EBSCO) publikováno 81 studií odvolávajících se na zakotvenou teorii, v 90. letech šlo již o 1485. K těmto údajům pak připojme, že využití zakotvené teorie v českém a slovenském pedagogickém výzkumu bylo o něco pozdější a došlo k němu intenzivněji až po roce 2005 , kdy byly publikovány nejenom první výše zmíněné metodologické statě, ale i výzkumy založené na bázi zakotvené teorie Strausse a Corbinové (viz dále - poznámka 6). Toto načasování se dnes zdá být poněkud nešt’astné, protože v okamžiku, kdy byla klasická zakotvená teorie uváděna do České republiky a na Slovensko, v mezinárodní komunitě procházela ostrou kritikou, doprovázenou vznikem nových odnoží. 
z řad vlastních protagonistů zakotvené teorie. Velkou část této kritiky přinesl epistemologický obrat, označovaný někdy jako „postmoderní“ (James \& Mills, 2005) či „kulturní“ (Bonnell, Hunt, \& Biernacki, 1999), jindy jako „interpretativní“ (Outhwaite \& Turner, 2007) nebo „pragmatický“ (Šíp, 2015).

Tento obrat či z jiného úhlu pohledu jen množina dílčích (půl)obratů přinesly do společenských věd tři vzájemně propojené body: (1) rozsáhlou kritiku pozitivismu ve všech jeho formách, zvláště pak pozitivistické epistemologie a metodologie; (2) přenesení důrazu na analýzu kultury, která je reprezentovaná především jejími materiálními a sémantickými formami, tzn. chápání kultury jako soustavy materiálních (ne-lidských) elementů a universa diskursů překračujících jednotlivé subjekty; (3) položení těžiště výzkumné práce a metodologických postupů na problematiku interpretativního porozumění významům aktérů a badatelů.

$\mathrm{Z}$ těchto tří myšlenek čerpá naprostá většina kritiky zakotvené teorie první generace, která upozorňuje na to, že pro klasickou zakotvenou teorii je charakteristická:

1) Př́lišná pozitivistická orientace, která se projevuje v úzkostlivé rigidnosti a mechaničnosti výzkumných postů, jež při střetu s heterogenním a měnícím se empirickým terénem narážejí na nutnost modifikace technik sběru a analýzy dat (Layder, 1998; Suddaby, 2006). Podle některých autorů (např. Richardson, 1994; Thomas \& James, 2006) má pak objektivistická zakotvená teorie rovněž tendenci považovat odlišné výsledky $\mathrm{v}$ datech za deviantní př́ípady a dopouštět se různých forem redukcionismu, které se týkají nejen okleštění výzkumné situace na jeden zkoumaný jev, ale i neúměrného zevšeobecňování významů do podoby schematických kategorií. Za část pozitivistického dědictví klasické zakotvené teorie je rovněž považováno implicitní prosazování příčinnosti do analýzy dat v podobě tzv. osového/axiálního modelu a její domnělý induktivismus (Dey, 1999; Prus, 1996), který Löic Wacquant (2002, s. 1481) dokonce označuje za „epistemologickou pohádku“. Mnoho autorů (např. Kelle, 2007; Reichertz 2007) proto v posledních letech raději zdůrazňuje, že poznávání v rámci zakotvené teorie ve skutečnosti předpokládá určitou ontologii a teoretické prekoncepty, a tudíž je lepší její epistemickou strategii považovat spíš za abduktivní nežli induktivní.

2) Podceňování úlohy kultury. Autoři (Clarke, Friese, \& Washburn 2015, s. 123) kriticky reflektují, že zakotvená teorie je až př́liš fixována na lidské jednání/chování, díky čemuž jí uniká role, kterou sehrává kultura 
ve své materiální a diskursivní formě při utváření lidské identity, prožívání a jednání. Díky tomu, že jsou zdůrazněny i tyto prvky, mohou být brány v potaz i další kulturní aspekty než jen výpovědi informantů, čímž se výzkum posouvá za úroveň znalého subjektu.

3) Minimální reflexivita výzkumných praktik, a to nejenom sběru dat, kdy jsou data konstruována v rámci interakce výzkumníků a subjektů/objektů výzkumu, ale i procesu jejich interpretace (kódování a poznámkování) a následné analýzy (viz např. Bryant \& Charmaz, 2007; Charmaz, 2000). Nedílnou součástí této reflexivity je přihlížení k mocenskému vztahu mezi výzkumníky a participanty výzkumu, zejména jsou-li ze subdominantních či jinak podřízených sociálních skupin, což je situace velmi typická pro pedagogický výzkum.

Jako reakce na tyto kritiky došlo k posunu od „zakotvené teorie k zakotveným teoriím" (Clarke et al., 2015, s. 15), který doprovázela profilace dvou stěžejních př́ístupů, jež jsou dnes považovány za hlavní reprezentanty druhé generace zakotvené teorie. Na jedné straně je to konstruktivistický př́stup Charmazové $(2000,2006)$, který se zaměřuje na problémy spojené s reflexivitou výzkumných praktik, jejichž vyřešením se chce autorka rovněž vypořádat $s$ problémy spojenými $s$ pozitivistickým založením zakotvené teorie Glasera, Strausse a Corbinové. Na straně druhé jde o situační analýzu Adele Clarkeové (2005, 2014; Clarke \& Charmaz, 2014; Clarke et al., 2015; Clarke, Friese, \& Washburn, 2016), pro niž je charakteristická mnohem radikálnější revize zakotvené teorie, jež se zaměřuje zejména na první a druhý bod její kritiky. Clarkeová (2014, s. 226) má totiž v úmyslu prostřednictvím rozsáhlé rekonstrukce pozitivistických základů zakotvené teorie a položením většího důrazu na úlohu materiální kultury a diskursů vytvořit teoreticko-metodologickou koncepci, která zakotvenou teorii „protlačí“ a „protáhne“ okolo postmoderního obratu. Navýšení badatelské reflexivity je až jejím sekundárním cílem. ${ }^{4}$ Jelikož se domníváme, že je právě tento př́stup mimořádně podnětný a metodologicky inovativní, věnujeme mu v této studii patřičnou pozornost.

\footnotetext{
Přes odlišnosti obou přístupů je třeba říci, že samy autorky vidí konstruktivistickou zakotvenou teorii a situační analýzu jako vzájemně komplementární (viz např. Charmaz, 2006; Clarke \& Charmaz, 2014). Zatímco situační analýza vhodně doplňuje postupy konstruktivistické zakotvené teorie, když přijde na analýzu faktorů, které jsou př́tomné ve zkoumané situaci a které se zejména týkají úlohy materiální a nemateriální kultury, konstruktivistická zakotvená teorie umožňuje doplnit situační analýzu celou řadou technik zvyšování reflexivity výzkumu.
} 
I když je situační analýza novou výzkumnou metodou, významně se rozvíjející až v poslední dekádě, rychle si vydobyla své místo v široké škále společenských a humanitních disciplín. ${ }^{5}$ Přes tento úspěch např́íc různými obory prozatím nedošlo k výraznému rozšiřrení situační analýzy do výzkumu vzdělávání, a to ani v zahraničí, ani v ČR. Tomu stále dominuje zakotvená teorie první generace a konstruktivistický přístup K. Charmazové. ${ }^{6} \mathrm{~V}$ oblasti věd o vzdělávání se tak prozatím můžeme setkat jen s několika málo studiemi (viz např. Harris, 2011; den Outer, Handley, \& Price, 2013; v ČR pak Kalenda \& Vávrová, 2015, 2016, v tisku), které vycházejí ze situační analýzy, a tudíž můžeme s trochou nadsázky označit situační analýzu za prozatím nevyužitou šanci pedagogického výzkumu.

Předložená studie se na tento deficit snaží reagovat tím, že kriticky představuje situační analýzu jako „balík teorie/metody“, který se jednak dokáže vyrovnat s kritikou objektivistické/pozitivistické zakotvené teorie první generace - díky tomu představuje adekvátnější výzkumný nástroj kvalitativně orientovanému bádání, než byla koncepce jejích předchůdců - a jednak otevírá možnosti zkoumání některých nových edukačních fenoménů, respektive přináší nové pohledy na studium těch stávajících. $V$ tomto ohledu může zásadním způsobem obohatit paletu metodologických přístupů používaných ke kvalitativnímu zkoumání (nejen) v tuzemské pedagogice.

5 Studie na bázi situační analýzy byly v posledních letech publikovány např. v antropologii, sociologii, psychologii, zdravotnictví, sociální práci, studiu vědy a technologií a mnoha jiných. 0 výrazném vlivu tohoto konceptu kupříkladu svědčí i to, že stěžejní publikace Adele Clarkeové Situational analysis: Grounded theory after the postmodern turn (2005) zaznamenala v posledních deseti letech 550 citačních ohlasů v databázi Scopus.

6 Co se situace v ČR týče, lze vysledovat dva směry v používání zakotvené teorie v pedagogickém výzkumu - ortodoxní a volně inspirovaný. Ortodoxní směr se explicitně odvolává na postupy klasické zakotvené teorie v podobě českého vydání Strausse a Corbinové (1999) použitím velké části jejího metodologického aparátu. $V$ tomto ohledu by se např. jednalo o výzkumy problematiky mediální výchovy (Šed'ová, 2005, 2006), estetické a výtvarné výchovy (Brücknerová, 2011), výukových strategií vedoucích k inkluzi (Ferdmanová, 2015) či rozhodování žáků základních škol o volbě další vzdělávací dráhy (Hlado, 2010). Volně inspirovaný směr naopak pracuje s klasickou zakotvenou teorií spíše implicitně. Bud’ se na ni odvolává skrze sekundární literaturu (Švařriček et al., 2007), nebo používá některý z analytických postupů volně, aniž by se přímo odkazoval na primární či sekundární práce (viz např. Bodláková, 2012; Sedláčková, 2015; Šed’ová, 2009). Jednu z výjimek z těchto dvou tradic představuje nedávno publikovaná studie Jaroslavy Simonové (2015) o postojích rodičů k volbě základní školy, čerpající z konstruktivistické zakotvené teorie K. Charmazové. 
Za účelem realizace tohoto záměru nejprve ukážeme ontologicko-epistemologická východiska situační analýzy ke studiu edukační reality a přiblížíme hlavní rozdíly oproti jiným variantám zakotvené teorie. Díky tomu budeme schopni demonstrovat, $\mathrm{v}$ čem je přístup situační analýzy inovativní na ontologicko-epistemologické úrovni. Poté se již konkrétně zaměříme na trojici hlavních metodologických nástrojů situační analýzy, jimiž jsou: (1) situační mapy, (2) mapy sociálních světů a arén a (3) poziční mapy, přičemž ukážeme nejenom, jak tyto „kartografické nástroje“ doplňují standardní postupy zakotvené teorie, ale na př́kladech ukážeme možnosti jejich využití při zkoumání rozmanitých edukačních jevů.

\section{Ontologicko-epistemologická východiska situační analýzy a pedagogický výzkum}

Situační analýza je podle Adele Clarkeové (2005, s. 23; Clarke \& Charmaz, 2014, s. 26) „balíkem teorie a metody“, což znamená, že na jedné straně činí zcela explicitními svá ontologická a epistemologická východiska a na straně druhé je neponechává bez nástrojů ke zkoumání reality. Vztah teorie a metody je zde vzájemně konstitutivní - jedno př́mo ovlivňuje druhé. V případě situační analýzy si tak podávají ruce osobitá ontologie vycházející z tradice pragmatické filosofie s inovovanými metodologickými postupy zakotvené teorie. Jako celek pak čerpá situační analýza ze čtveřice vzájemně propojených ideových zdrojů, které mohou být ve svém spojení inspirativní i pro předporozumění a poznávání celé řady pedagogických fenoménů.

Za prvé se jedná o symbolický interakcionismus, z něhož si bere tezi, podle níž sociální realita - tu edukační nevyjímaje - vzniká ze vzájemné interakce jedinců, jejich sdílení významů a opakovaného definování situací (např. Blumer, 1969). Právě propojení se symbolickým interakcionismem představuje pro Clarkeovou důležitý ontologický předpoklad, jímž se distancuje od pozitivistického zaměření svých předchůdců a spojuje zakotvenou teorii s konstruktivistickými či interpretativními př́ístupy.

Za druhé jde o teorii diskursu a moci Michela Foucaulta (2000), která umožňuje autorce doplnit zakotvenou teorii o dvojici důležitých bodů. Jednak o nový důraz na diskurs/diskursy, který je / které jsou součástí situace, jednak o otevřenou diskusi vlivu moci (tzv. mikropolitiky) na utváření významů jak 
mezi jedinci, tak v prostředí organizací a sociálních skupin, kde má působení diskursů disciplinační účinky a vytváří určitou formu subjektivity. ${ }^{7}$

Za třetí to je koncepce sociálních světů a arén, kterou zformuloval Anselm Strauss (1984). Pro ni je charakteristický pokus zachytit mezoúrovňové fenomény $\mathrm{v}$ podobě sociálních skupin, organizací a různých diskursivních arén, kde jsou vyjednávány významy prostřednictvím abduktivní logiky kvalitativní analýzy. $V$ tomto ohledu je zakotvená teorie rozš́iřena i o analýzu sociálních skupin a organizací, čímž překračuje mikrosociální zaměření tradiční zakotvené teorie.

Za čtvrté se jedná o tzv. studia vědy a technologie (např. Latour, 2005), které přinášejí důraz na materiální aspekty situace, jež bývají často při analýzách soustředěných pouze na činnost aktérů opomíjeným aspektem. Studia vědy a technologie popisují působení materiálních předmětů na jedince zasazené v různých situacích - tzn. jak omezují či umožňují jejich činnost (např. pohyb, vzájemnou komunikaci či povahu vztahů mezi nimi).

Jak tato čtyři východiska ovlivňují základní rámce kvalitativně orientovaného pedagogického výzkumu, který by měl podle Clarkeové obstát ve světle kritiky, již přinesl kulturní či interpretativní obrat?

V prvé řadě explicitní propojení se symbolickým interakcionismem předpokládá, že významy vzdělávání a učení, stejně jako výchovné praxe podléhají neustálému procesu definování a konstruování ze strany aktérů pedagogických procesů. Smyslem pedagogického výzkumu je v takovémto rámci daným významům a definicím co nejhlouběji porozumět, k čemuž pak mají sloužit i jednotlivé výzkumné postupy, které situační analýza navrhuje (viz část 4 této studie). Ostatně pro takto koncipovaný poznávací záměr kvalitativního pedagogického výzkumu argumentují i mnozí další autoři (Gordon, Holland, \& Lahelma, 2001; Wortham \& Jackson, 2008; v ČR např. Wiegerová \& Gavora, 2014, s. 511).

\footnotetext{
Je třeba říci, že autorčin výklad díla M. Foucaulta se opírá zejména o jeho „americké čtení“ zprostředkované Paulem Rabinowem. Clarkeová navíc nezachází s Foucaultovými koncepty nijak kanonicky, např. vůbec nerozlišuje mezi jeho strukturalistickým a poststrukturalistickým obdobím, ale naopak ryze pragmaticky. Koncepty moci a diskursu jí slouží coby senzitivní kategorie, které jí umožňují teoreticky uchopovat a konceptualizovat část empirických dat, k nimž varianty zakotvené teorie Strausse a Glasera neměly doposud vhodný pojmový aparát, a kvůli tomu je nemohly adekvátně zachycovat.
} 
Dále pak využití Foucaultova konceptu moci a diskursu umožňuje zdůraznit, že významy nejsou aktéry konstruovány libovolně, ale vždy závisejí na mocenských vztazích a diskursech organizací a skupin (např. určité mateřské školy nebo školní třídy), jichž jsou jedinci součástí. Domníváme se, že toto teoretické východisko situační analýzy je v mnoha ohledech komplementární s nedávno realizovanými výzkumy některých českých a slovenských autorů (viz např. Makovská, 2011; Šed’ová, 2015), kteří více či méně explicitně přebírají Foucaultovo stanovisko ohledně moci ve školní třídě či školních institucích. Exemplární je v tomto ohledu tvrzení Šed’ové (2015, s. 33), která píše, že „moc je ve školních třídách všudypřítomná, nikdy se z interakcí nevytrácí a nepřetržitě se přelévá mezi učitelem a žáky, nebot' obě skupiny sledují cíle, jichž chtějí dosáhnout". Jinými slovy řečeno, naprostá většina pedagogických jevů zahrnuje určitý mocenský rozměr, který má být do analýz zahrnut.

Ačkoliv je zakotvená teorie běžně považována za vhodný nástroj analýzy edukačních mikrojevů, situační analýza vytváří předpoklady i pro studium významů na edukační mezoúrovni - tzn. pro to, jak vznikají a jsou vyjednávány významy, které reprezentují celé skupiny nebo organizace. $V$ případě pedagogiky se může např. jednat o způsoby vyjednávání významů určité školní reformy u různých zájmových skupin - např. vlády, ministerstva školství, pedagogů z různých typů středních a jiných škol, profesních sdružení učitelů, žáků a jejich rodičů. Každá z těchto skupin může s ohledem na to hájit jiné stanovisko (skupinu významů), které se pak v diskursivní aréně snaží prosadit jako dominující definici reformy. Jiným př́kladem mohou být významy týkající se některých témat spjatých s určitou školou, kde jsou významy výsledkem vyjednávání mezi zástupci školy, rodiči a krajskou či městskou samosprávou. $\mathrm{K}$ těmto tématům jsou v české pedagogice nejčastěji používány případové studie čerpající z metodologie Roberta K. Yina (2002). Pakliže je $\mathrm{v}$ nich kvalitativní metodologie $\mathrm{v}$ podobě zakotvené teorie použito, zpravidla slouží „jen“ ke zjištění významů určité skupiny aktérů - např. ředitelů škol (Pol et al., 2009, 2010). V takovéto podobě se však kvalitativní výzkum pohybuje stále na edukační mikroúrovni a neumožňuje zachytit významy, které jsou charakteristické pro celé organizace či pro sociální skupiny, které vstupují do vyjednávání těchto významů, což právě umožňuje situační teorie.

Poslední z teoretických předpokladů nás vede $\mathrm{k}$ tomu, že při analýze edukační reality si nemůžeme dovolit opomenout ani materiální a prostorové aspekty zkoumaného "terénu“ - např. to, jak technika a technologie ovlivňují pedagogické prostředí a jeho prostorové rámce. Třebaže se podle Rißlera, 
Bossena a Blasse (2014) jedná o teprve postupně emergující téma, je podle nás třeba mu věnovat patřičnou pozornost. $V$ tomto ohledu lze uvést přinejmenším dva příklady. Dílem se jedná o sledování vlivu různých druhů technologií, zejména ICT, které vstupují - at' už záměrně, nebo ne - do edukačního prostředí a vedou k jeho transformaci, dílem se jedná o materiální konstituci vzdělávacího prostředí, jeho architekturu, která ovlivňuje komunikaci mezi vyučujícím a studenty.

Unikátnost teoreticko-epistemologických východisek situační analýzy nespočívá v odděleném zdůrazňování výše zmíněných aspektů edukační reality, ale v jejich syntéze. Situační analýza totiž zdůrazňuje, že výzkumníci by při zkoumání určitého jevu neměli přihlížet jen $\mathrm{k}$ jevu samotnému, ale k celé situaci, která ho konstituuje a v níž jsou přítomné jak materiální a diskursivní prvky, tak aktéři, kteří v závislosti na vzájemných mocenských vztazích aktivně konstruující význam v rámci určitého sociálního světa (např. školy, školní třídy) či diskursivní arény (např. veřejné debaty ohledně měření kvality vzdělávání).

Od tohoto požadavku se tak dostáváme k dalším bodu, který podstatným způsobem odlišuje situační analýzu od jiných výzkumných postupů a který z ní činí vhodný rámec pedagogicky orientovaného zkoumání. Jde o alternativní epistemologický přístup k předmětu výzkumu, jímž Clarkeová řeší podstatnou část epistemologické kritiky, již přinesl postmoderní obrat do společenských věd.

\section{$3 \quad$ Situace jako základní jednotka analýzy}

Podle Clarkeové (2014, s. 241) má být sama situace zkoumání základní jednotkou analýzy. Předmětem našeho výzkumu by tudíž neměl být jen určitý jev, tzn. nejčastěji určitá forma jednání či chování v podobě výchovného stylu rodičů, identity pedagoga na malé základní škole či regulace emocí vyučujícího v průběhu lekce cizího jazyka, ale celá situace, která tyto jevy zahrnuje a spoluutváří, včetně výzkumníků, kteří do ní svou přítomností a působením intervenují. Z hlediska výzkumu se tudíž nezaměřujeme jen např. na výchovný styl rodiče, ale též na vše, co k němu náleží a co lze prostřednictvím výzkumu zachytit $\mathrm{v}$ datech $\mathrm{v}$ podobě terénních poznámek, výpovědí informantů či skrze rozbor dokumentů. $V$ uvedeném př́kladu to znamená, že se zaměřujeme i na děti a další rodinné příslušníky, kteří do výchovy intervenují, 
na předcházející zkušenosti rodičů s výchovou dětí, na populární i odborné diskursy o výchově, $\mathrm{k}$ nimž se informanti vztahují, stejně jako na média a jiné materiální nástroje, které jsou k výchovné praxi používány.

Strauss a Corbinová (1990, s. 163; 1998, s. 184) se v tradiční zakotvené teorii sice snažili roli situace do určité míry řešit vypracováním tzv. matice podmínek, která zachycuje kontext zkoumaného jevu a prvky, které ovlivňují lidské chování/jednání zvenčí, nicméně Clarkeová (2009, s. 208) s takovouto konceptualizací situace nesouhlasí, nebot’ podle jejích vlastních slov „podmínky situace jsou v situaci. Kontext neexistuje." Tímto provokativním tvrzením chce autorka upozornit na to, že členění na jev a kontext je arbitrárním zásahem výzkumníka a je aktem, který je možné provést a ospravedlnit na analytické úrovni, nikoliv však již na úrovni ontologické. Navíc jí dané východisko umožňuje ukázat, že všechny prvky se v určité situaci vzájemně konstituují a ovlivňují, následkem čehož nelze provést jednoduchou redukci na jev a jeho podmiňující okolí. Studovaný jev totiž vždy ovlivňuje další fenomény ve svém „okolí", stejně jako je jimi ovlivňován.

Situací je Clarkeovou chápána množina všech prvků, které utvářejí zkoumaný fenomén svým působením a které lze podložit empirickými daty. Časový i prostorový rozsah situace je pak opětovně diktován jen dostupnými daty, které výzkumník získá bud' rozhovory s informanty, nebo jinými technikami kvalitativní konstrukce dat. 0 tom, co patří do situace, tudíž vždy rozhodují data získaná výzkumníkem. $Z$ tohoto důvodu musí být výzkumník vždy součástí situace a musí popsat, jakým způsobem spolutvořil danou situaci.

Přenesení analytického důrazu z jednání na situaci neredukuje zkoumaný jev na předem identifikované projevy lidského jednání/chování a nevytrhává jej ze vztahů, které jej (spolu)utvářejí, čímž je udržena komplexnost celé zkoumané situace. Zároveň to ve zkoumané situaci umožňuje zachycovat i unikátní a partikulární elementy, na které nemusí být brán zřetel, pakliže se výzkumník již od počátku soustředí pouze na jeden hlavní jev.

V této epistemologické strategii lze spatřit několik podstatných rozdílů a výhod oproti klasické zakotvené teorii. $V$ prvé řadě situační analýza nabízí mnohem komplexnější popis zkoumaného terénu. Snaží se o podrobné mapování všech jeho prvků a o postižení unikátnosti zkoumané situace, což vede $\mathrm{k}$ mnohem adekvátnějšímu zachycení reality než v př́ípadě tradiční zakotvené teorie, která spěje ke skicovitému vidění světa reprezentovaného generalizovanými kategoriemi a axiálním kódováním. $V$ druhé řadě zaměření 
na situaci umožňuje věnovat se i okrajovým prvkům, které se v tradiční zakotvené teorii často stávají jen součástí obecně pojímaného kontextu zkoumaného jevu, a není patrné, jak s daným jevem souvisejí, respektive jak ho ovlivňují.

Předmětem pedagogického výzkumu, který akcentuje epistemologickou premisu Clarkeové, je tudíž celá edukační/výchovná situace, nikoliv jen určitý edukační/výchovný fenomén - např. komunikace vyučujícího s žáky, vnímaná zdatnost studenta či jeho motivace -, ale veškeré prvky, které je spolukonstituují a př́mo či nepřímo ovlivňují. Záměr poznávání edukačních jevů pak musí spočívat v zachycení jejich neredukované komplexnosti. Domníváme se, že takovýto přístup k předmětu pedagogického výzkumu je komplementární s tím, jak Wortham a Jackson (2008, s. 107) chápou oblast pedagogických jevů, tedy jako „neuspořádanou (fuzzy) množinu procesů, které se odehrávají v institucích či v podobě událostí a které zahrnují neformální socializaci i formální učení." Kladení důrazu na situaci umožňuje činit onu neuspořádanou množinu procesů zřetelnější a poukazovat na jejich propojenost.

Představená epistemologická strategie není samozřejmě jedinou možnou a nutnou cestou poznávání pedagogických jevů. Je využitelná zejména pro výzkumné otázky, které jsou spojeny s jasně identifikovatelnými skupinami informantů, jakou jsou např. žáci určité třídy, učitelé určité školy či rodiče preferující určitou formu předškolní výchovy. U takových skupin informantů lze poměrně dobře popsat celou jejich situaci a všechny elementy, které ji konstituují. $V$ tomto ohledu je možné si klást výzkumné otázky jako: Jak funguje neformální autorita u žáků $v$ dané třídě? Jaká je profesní identita vyučujících dané školy? Jaké výchovné strategie používají otcové a matky? Pokud se ale výzkumný soubor - potažmo sféra dat, z níž se vychází - příliš rozšíríi či zmenší, přestávají být postupy situační analýzy z poznávacího hlediska užitečné. Při zvětšení výzkumné jednotky či zmnožení skupin informantů se totiž výrazně navýší komplexnost celé situace - množství elementů, jež jsou v ní přítomné, a díky tomu se stává analytickými postupy situační analýzy těžko postižitelnou. Naopak při jejím výrazném zmenšení, na několik málo jedinců, neumožňuje dostatečně podrobně mapovat vnitřní prožívání aktérů a způsoby, jimiž vytvářejí svůj obrázek vzdělávacích fenoménů. Pro tyto účely jsou mnohem výhodnější jiné výzkumné metody, např. nějaká $\mathrm{z}$ forem narativní nebo diskursivní analýzy. 


\section{$4 \quad$ Analytické postupy situační analýzy a pedagogický výzkum}

Z hlediska výzkumného postupu situační analýza ve své úvodní fázi spoléhá na velmi podobné analytické strategie jako klasická zakotvená teorie. I v jejím př́ípadě dochází k rozsáhlému otevřenému kódování a poznámkování, díky čemuž má být dosaženo základní interpretace získaných dat. Co však situační analýzu odlišuje od jiných forem zakotvené teorie, je tvorba různých forem map ve všech fázích výzkumu, které jsou jak pomůckami pro další zkoumání, tak i výslednými produkty analýz. Navíc mapy mají výzkumníkům sloužit nejenom k co nejhlubšímu pochopení celé situace - tzn. veškerých elementů, jež jsou v situaci př́tomné a které ji spoluutvářejí -, ale také je mají vést $\mathrm{k}$ mnohem vyšší míře sebe-reflexivity, nebot' se mají sami do těchto map umístit, a tím reflektovat svou pozici ve výzkumné situaci (Clarke et al., 2015, s. 16).

Mapy nejsou jen samoúčelnými grafickými výstupy analýz, ale v prvé řadě vizuálními pomůckami, které mají sloužit holistnímu zachycení prvků přítomných v situaci a jejich vztahů. K tomuto účelu je lze využít již v úvodních fázích výzkumu, kde mohou plnit roli nástroje pro zaměření dalšího zkoumání či sledování progresu ve výzkumu. Jejich výhoda spočívá zejména v tom, že situaci a její komplexnost činí neustále viditelnou a přehlednou. Tím se však samotná analýza nikdy nevyčerpává, nebot' jednotlivé elementy a jejich vztahy musí být vždy náležitě popsány, čímž teprve získávají svou analytickou hloubku.

Clarkeová $(2014$, s. 240-241) pro účely situační analýzy nabízí celkově tři kartografické nástroje, které vycházejí z jejích ontologicko-epistemologických východisek a odlišného nahlížení předmětu bádání:

1) situační mapy;

2) mapy sociálních světů a arén;

3) poziční mapy.

Každý z těchto tří nástrojů představuje odlišný způsob kódování a reprezentace získaných dat a jejich vzájemných vztahů. S trochou nadsázky lze říci, že se jedná o tři různá měřítka, jimiž výzkumník může zachycovat různé aspekty zkoumaného terénu. Zatímco situační mapy jsou vhodné k co nejdůkladnější analýze určité mikrosociální situace, k její „zhuštěné analýze“ (Fosket, 2015), 
mapy sociálních světů jsou určené k rozboru významů na mezoúrovni skupin a organizací. Konečně poziční mapy, jak jejich název napovídá, umožňují zachytit různé pozice participantů výzkumu a/nebo diskursů skupin a organizací ve vztahu k určitým tématům/problémům, které se nacházejí ve zkoumané situaci. Všechny tři typy map, pakliže to získaná data umožňují, lze použít jak odděleně, tak i najednou jako tři různé způsoby nahlížení výzkumného problému. Právě využití různých „měřítek“, jimiž lze ke zkoumané situaci přistoupit, zmnožuje jednak využitelnost situační analýzy oproti klasické zakotvené teorii a jednak přináší mnohem komplexnější zachycení reality.

\subsection{Situační mapy}

Pro situační mapy je charakteristické, že slouží k zachycení všech stěžejních elementů př́tomných ve zkoumané situaci bez rozdílu, o jaký typ elementu se jedná (např. jedince, sociální skupinu, chování, emoce, diskurs, význam či materiální prvek), a jejich vzájemných vztahů. Pro tento účel se používají dva typy situačních map. Prvním typem jsou tzv. neuspořádané mapy (messy maps), které prezentují všechny stěžejní elementy přítomné v určité zkoumané situaci. Druhým typem jsou tzv. relační mapy (relational maps), které ukazují vzorec vztahů mezi těmito elementy.

Pro lepší přehlednost dalšího výkladu níže prezentujeme tři ukázky situačních map (viz obrázky 1 až 3) z výzkumu učení studentů kombinovaného studia pomáhajících profesí (Kalenda \& Vávrová, v tisku). Všechny tři zachycují stejnou výzkumnou situaci prostřednictvím: (1) základní neuspořádané mapy, (2) relační mapy se zaměřením na řízení podmínek učení a (3) relační mapy se zaměřením na motivaci $\mathrm{k}$ učení/studiu.

Zatímco neuspořádané mapy vznikají prostým přenesením klíčových elementů vzniklých otevřeným kódováním do mapy, v případě relačních map dochází již k načrtnutí vzájemných vztahů mezi jednotlivými elementy. Vztahy mezi nimi jsou identifikovány prostřednictvím analýzy dat, při níž badatel v mapě zvolí jeden výchozí element a následně v datovém materiálu hledá veškeré vztahy mezi tímto elementem a elementy dalšími. Jedná se tudíž o aplikaci principu neustálé srovnávací analýzy, která je průvodní logikou zakotvené teorie (Hallberg, 2006). Povaha výsledných vztahů nemusí být nutně kauzální, jelikož může jít o nejrůznější formy vzájemného ovlivňování jednotlivých elementů. Vztahy v mapě lze pak podle potřeb analýzy dodatečně vizuálně odlišovat. Na příkladu obrázků 2 a 3 jsou kupříkladu odlišeny vztahy přímého (plná čára) a zprostředkovaného působení (přerušovaná čára). 


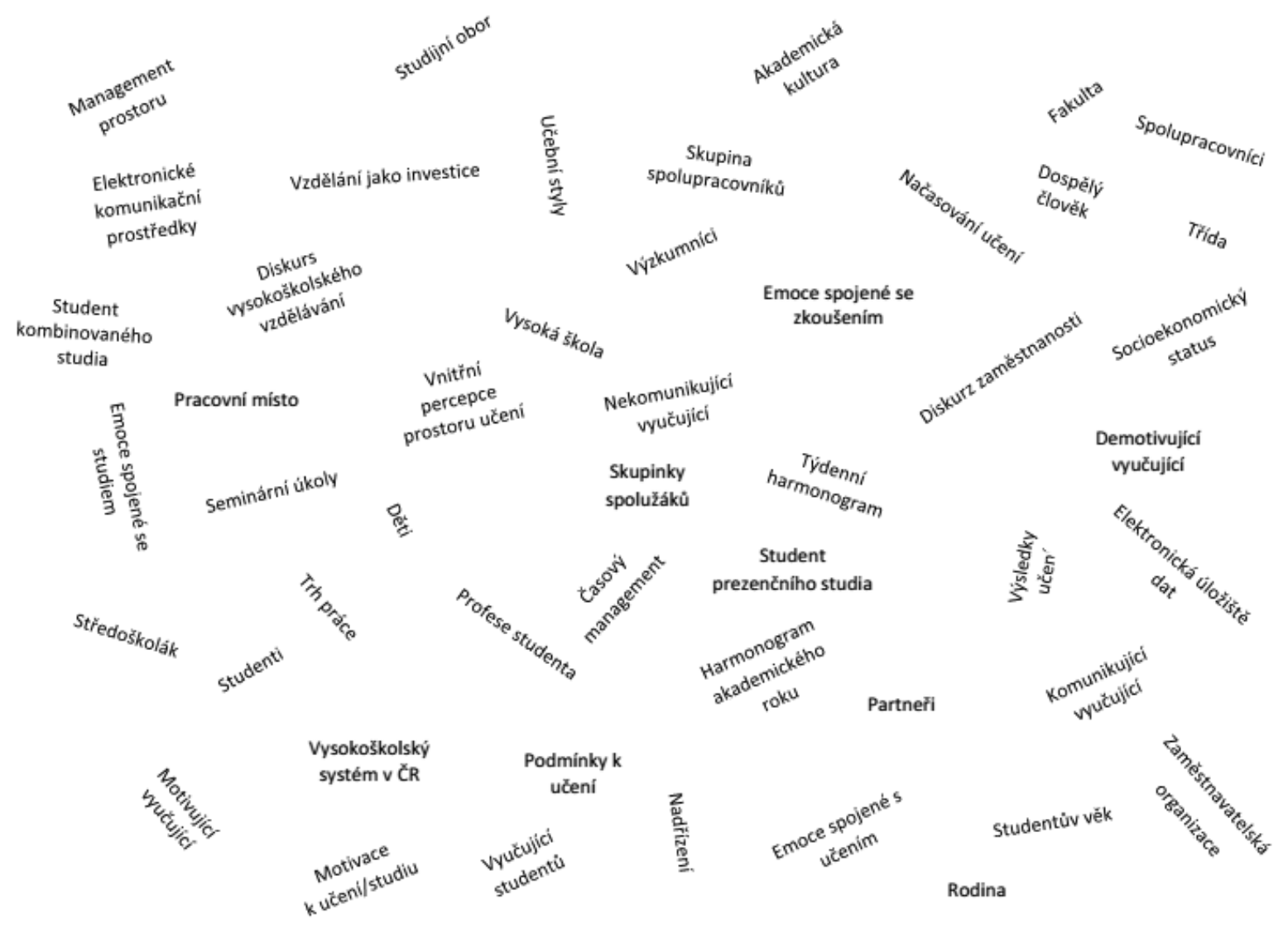

Obrázek 1. Neuspořádaná mapa - Řízení učení studentů kombinovaného studia pomáhajících profesí. Převzato z Kalendy a Vávrové (v tisku).

Při generování těchto spojnic sehrává stěžejní úlohu datový materiál a tvorba poznámek. Spojnice vznikají totiž jen tehdy, je-li možné v datech identifikovat určitý typ vztahu mezi výchozím prvkem, k němuž se vztahuje daná analýza, a zbývajícími elementy. $V$ př́ípadě obrázku 2 tak $v$ datovém materiálu informanti popisovali, jak jejich rodina ovlivňuje řízení podmínek jejich učení, nicméně o vztahu k jinému z elementů - diskursivní konstrukci jejich věku - nebyly v datech žádné informace.

Sestavení relační mapy je $\mathrm{z}$ analytického hlediska jen prvním výchozím krokem analýzy situace, nebot' $v$ tom druhém musí výzkumník prostřednictvím textu popsat onu povahu vztahu - jaký je charakter onoho působení. Jinými slovy řečeno, narativně reprezentovat obsah spojnic $\mathrm{v}$ mapě. $\mathrm{V}$ tomto ohledu sehrává tvorba poznámek k datovému materiálu mnohem větší úlohu než u klasické zakotvené teorie, nebot' na kvalitě a rozsahu poznámek závisí popis vztahů mezi jednotlivými prvky situace. 


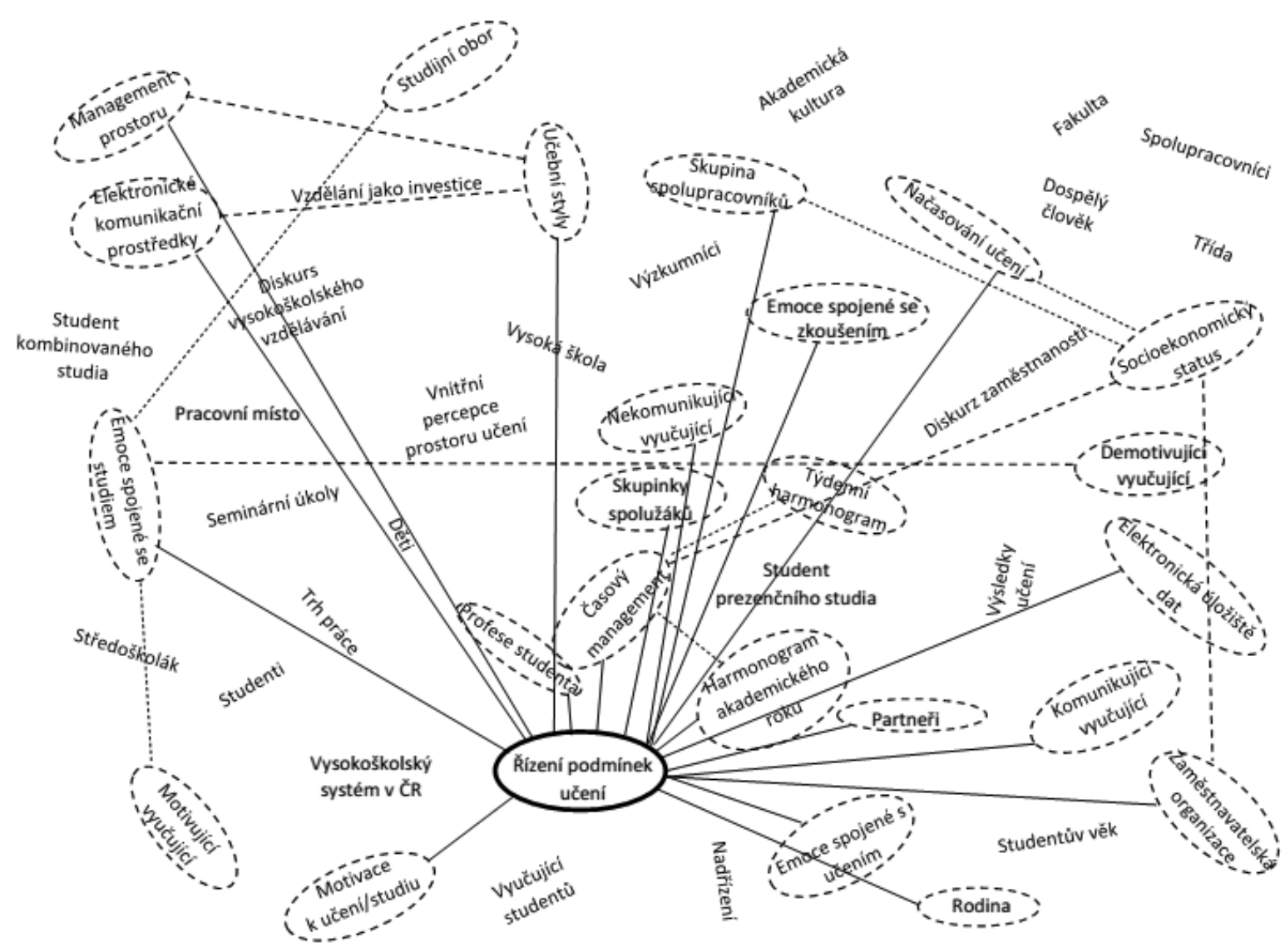

Obrázek 2. Relační mapa - Zaměření na řízení podmínek učení studentů kombinovaného studia pomáhajících profesí. Převzato z Kalendy a Vávrové (v tisku).

Vytvoření neuspořádané mapy umožňuje výzkumníkům získat základní obrázek o studované situaci a její mnohorozměrnosti a komplexnosti. Zároveň je vede k opětovnému promýšlení vlastního výzkumu, nebot' by se měli při její tvorbě pozastavovat nad tím, zdali do mapy skutečně integrovali veškeré prvky, které jsou součástí zkoumané situace a datového materiálu o ní (získaného napřs skrze rozhovory, analýzou dokumentů, pozorováním či poznámkováním). Tvorba relačních map se liší ve své snaze nabídnout analýzu vztahů mezi jednotlivými prvky situace. Na rozdíl od axiálního kódování v klasické zakotvené teorii (Strauss \& Corbin, 1990, 1999) neuspořádává data do implicitního kauzálního modelu od příčinných podmínek přes hlavní kategorie a kontext jevu až po jeho výsledky. Naopak umožňuje pro analýzu zvolit více elementů nacházejících se v situaci a ty podrobit relační analýze samostatně. Díky tomu nabízí mnohočetnou interpretaci a analýzu dat. 


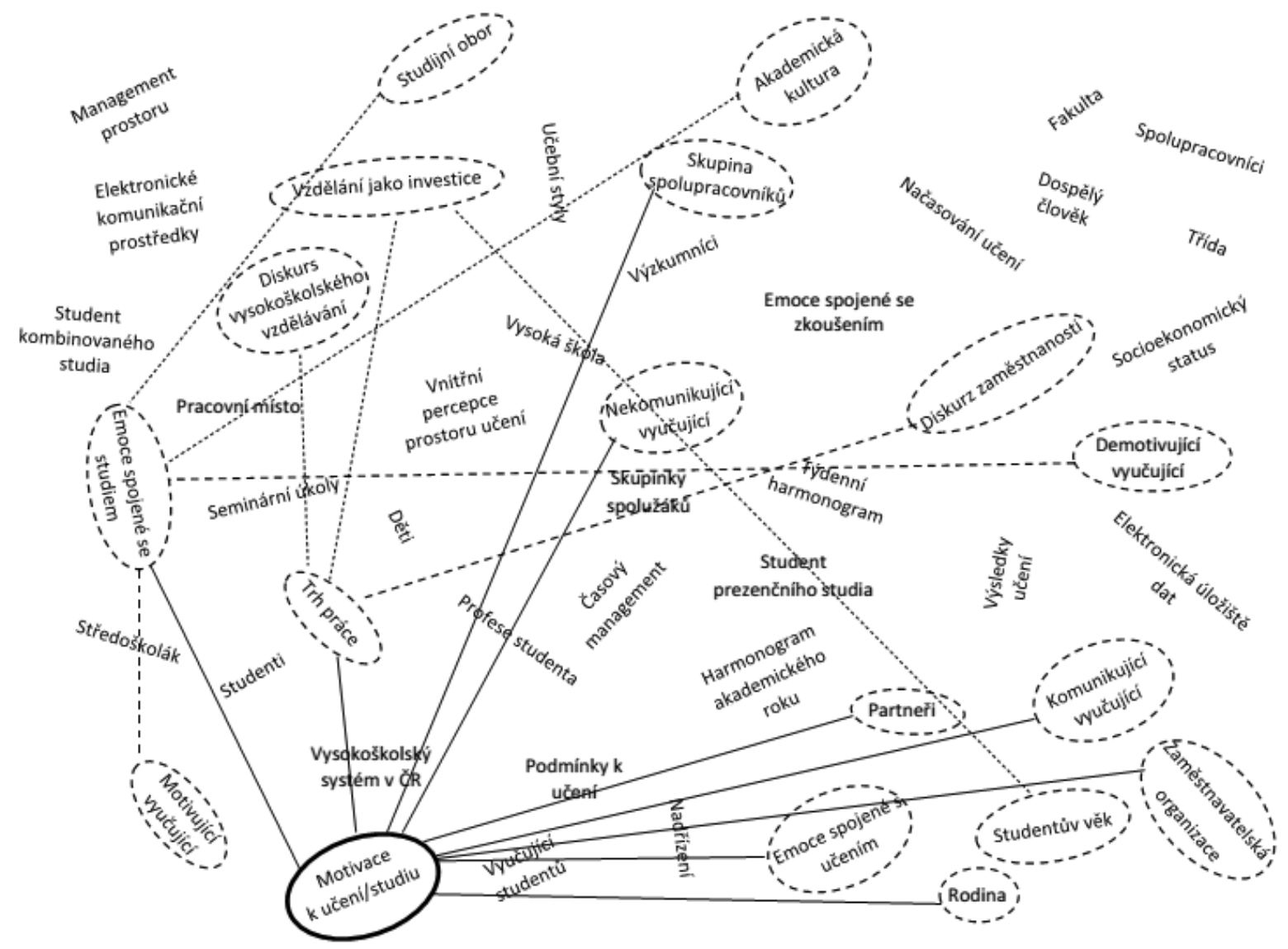

Obrázek 3. Neuspořádaná situační mapa - Zaměření na motivaci k učení/ studiu studentů kombinovaného studia pomáhajících profesí. Převzato z Kalendy a Vávrové (v tisku).

Výhody této strategie je možné ilustrovat na obrázcích 2 a 3, kdy je z identické situace vybrán nikoliv jeden, ale dva jevy, které souvisejí s učením studentů kombinovaného studia. Na jedné straně je to řízení podmínek učení a na straně druhé jde o jejich motivaci. Z obou obrázků je patrné, že vzorec elementů, který je ovlivňuje, je značně rozdílný a vyžaduje samostatnou interpretaci. Pokud bychom elementy převáděli do tradičního paradigmatického modelu, došlo by k jejich výrazné schematizaci a redukci. Díky tomu by kupříkladu nebylo možné vidět komplexní vztahy mezi prožíváním emocí, motivujícími a nemotivujícími vyučujícími, charakterem studijního oboru a řízením podmínek k učení v př́ípadě prvního schématu (viz obrázek 2) nebo vztahem mezi motivací, vyobrazováním trhu práce a dvěma diskursy, k nimž se studenti vztahují (viz obrázek 3). 


\subsection{Mapy sociálních světů a arén}

Pokud zvětšíme pomyslné měřítko pro zachycení studovaných jevů, dostáváme se od situačních map k mapám sociálních světů a arén, které zobrazují větší a hrubší kontury sociální/edukační reality. Tento druh map se zaměřuje na určení tři stěžejních prvků: (1) klíčových sociálních skupin (např. rodičủ žáků), (2) organizací (např. soukromých vysokých škol) a (3) arén, což jsou diskursivní prostory, $v$ nichž dochází k vyjednávání významů. V porovnání se situačními mapami představují mapy sociálních světů a arén nástroj porozumění situaci aktérů na sociální/edukační mezoúrovni, který slouží k pochopení toho, jak se u jedinců vytvářejí závazky, např. v podobě identit, k různým sociálním skupinám, jak skupiny mezi sebou vyjednávají určitý význam či jak je situace ovlivněna diskursy, které se nacházejí v dané organizaci.

Mapy takovýchto diskursivních arén a sociálních světů lze použít prakticky $\mathrm{v}$ jakékoliv oblasti edukačního výzkumu, $\mathrm{v}$ níž máme co do činění $\mathrm{s}$ větším množstvím sociálních skupin a organizací, které spojuje určitá diskursivní aréna. Jako zdroje dat pro konstrukci těchto map pak mohou sloužit nejenom rozhovory a pozorování, ale i další dokumenty (např. výroční zprávy, informace z webových stránek škol, PR materiály či diskuse z internetových fór), které jsou kódovány se záměrem identifikovat stěžejní diskursivní témata, sociální skupiny a vztahy daných skupin $\mathrm{k}$ těmto tématům.

Vhodným příkladem použití map sociálních světů a arén pro oblast vzdělávání může být mapa týmu Birgit den Outerové a kol. (2013, s. 1513), která pokrývá problematiku hodnocení studentů na vysoké škole zaměřené na obchod (viz obrázek 4). Problematika hodnocení studentů je zde zvolena jako klíčová oblast diskusí, tedy jako diskursivní aréna, v níž je aktéry z různých sociálních světů alternativně interpretována a konstruována problematika hodnocení, včetně vznášení různých, častokrát kontradiktorních požadavků na studenty. Autorky (den Outer et al., 2013) do této mapy začlenily veškeré sociální skupiny a organizace, tj. sociální světy, které vstupují do arény hodnocení: např. studenty, vyučující z praxe v podobě odborníků na obchod (business experts), akademické odborníky na určitá témata (topics experts), běžné vyučující, výzkumné centrum, výzkumníky, studenty, osoby zodpovědné za realizaci určitých vzdělávacích modulů aj. Autorky následně $\mathrm{v}$ analýze zachycují nejenom to, jak se tyto různé skupiny a organizace podílejí na vytváření podoby hodnocení na dané vzdělávací instituci, ale i to, jak si jedinci k jednotlivým skupinám vytvářejí závazky a na základě jakých kritérií přistupují k problematice hodnocení studentů. 


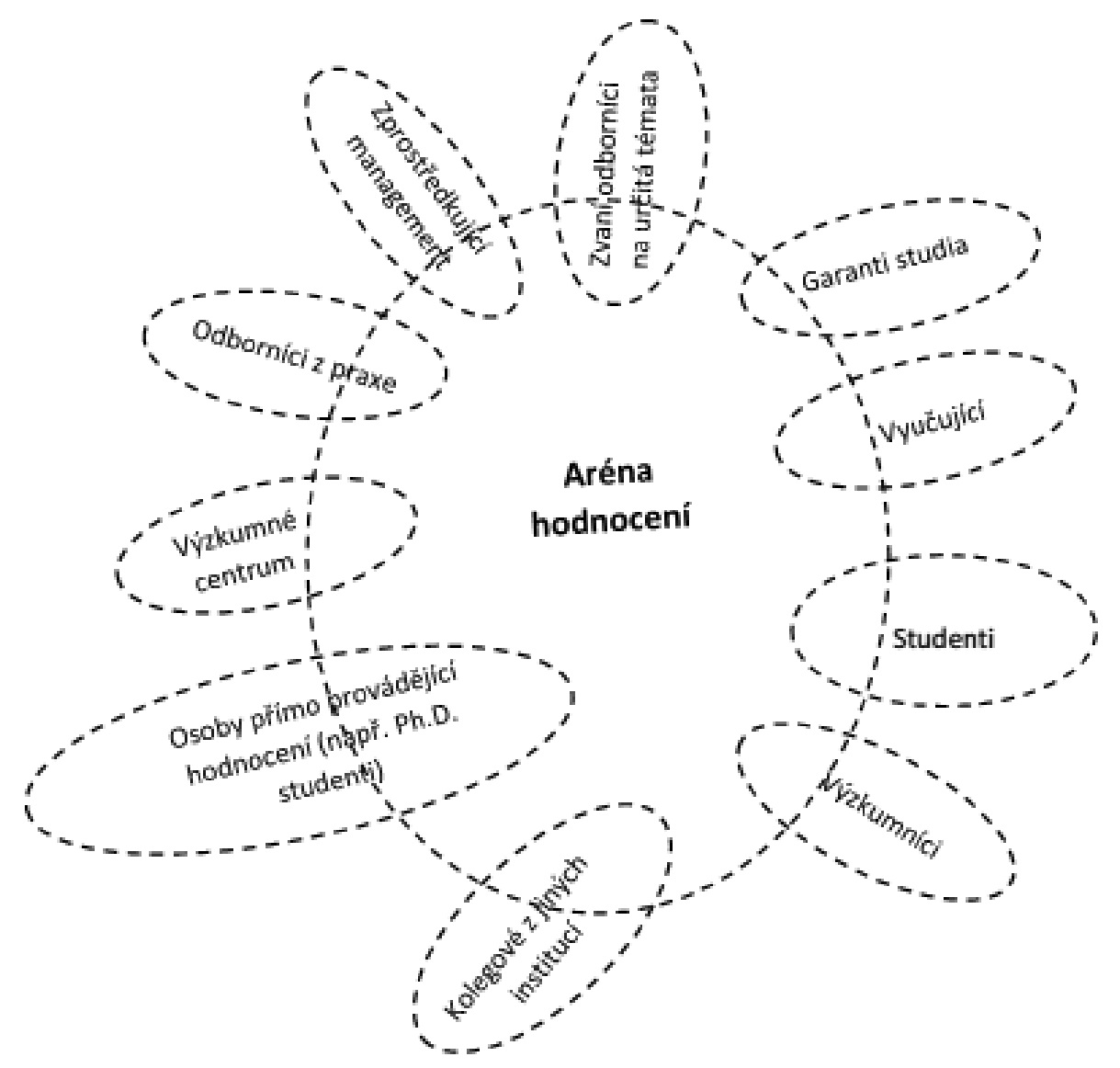

Obrázek 4. Mapa sociálních světů a arén - hodnocení studentů na vysoké škole. Upraveno podle den Outerové a kol. (2013, s. 1513).

Zvláště zajímavé a přínosné je využití takovéhoto druhu map v rámci výzkumu orientovaného na změnu, $v$ němž lze použitím dvou map $\mathrm{z}$ různých časových období (např jedné z roku 1995 a druhé z roku 2015) dokumentovat měnící se výzkumné prostředí, do něhož mohou přibývat noví aktéři či mizet ti stávající, případně sledovat, jak v dané diskursivní aréně převládají či se mění určité typy významů a způsoby jejich prosazování. Použití map sociálních světů tak může být velmi vhodným nástrojem nejenom pro porozumění některým aktuálním otázkám pedagogického výzkumu (např. určité školské reformě), ale i pro longitudinální sledování určitých arén (např. diskuse o povaze dalšího vzdělávání nebo předškolní výchovy v ČR) a organizací (např. proměny vzdělávacích strategií určité vysoké školy). 


\subsection{Poziční mapy}

Jednou z často kritizovaných vlastností klasické zakotvené teorie je až př́lišné zjednodušování významů, během něhož jsou odchylky ve výpovědích účastníků výzkumu od ústředních významových kategorií nereflektovány nebo zahlazovány jako odchylky od normy (Clarke, 2003, 2005; Thomas \& James, 2006). V reakci na tuto kritiku situační analýza vyprodukovala poslední ze svých analytických nástrojů - tzv. poziční mapy, které umožňují nahlížet různorodé významové pozice zastávané či nezastávané jedinci $\mathrm{v}$ dané situaci. Zpravidla se tento typ map používá jako poslední krok situační analýzy.

Principem tvorby pozičních map je stanovení dvou významových os, které lze nalézt okolo hlavních témat či problémů identifikovaných ve zkoumané situaci. Každá osa by měla mít dva krajní póly, z nichž jeden označuje nižší výskyt určitého významu či praktiky, kdežto ten druhý vyšší. Na obrázku 5 uvádíme příklad aplikace poziční mapy na hypotetický výzkum učebních stylů žáků. Zatímco jednu z os tvoří používání vizuálních učebních stylů, které variuje na škále od nízké až po vysokou, druhou osu v tomto případě tvoří aplikace verbálních strategií. $\mathrm{V}$ mapě jsou pak na základě úryvků vyprávění informantů zaneseny pozice (P1 až P4), které zastávají vzhledem k těmto dvěma významovým osám - zdali jsou jejich učební strategie spíše vizuální, verbální nebo obojí.

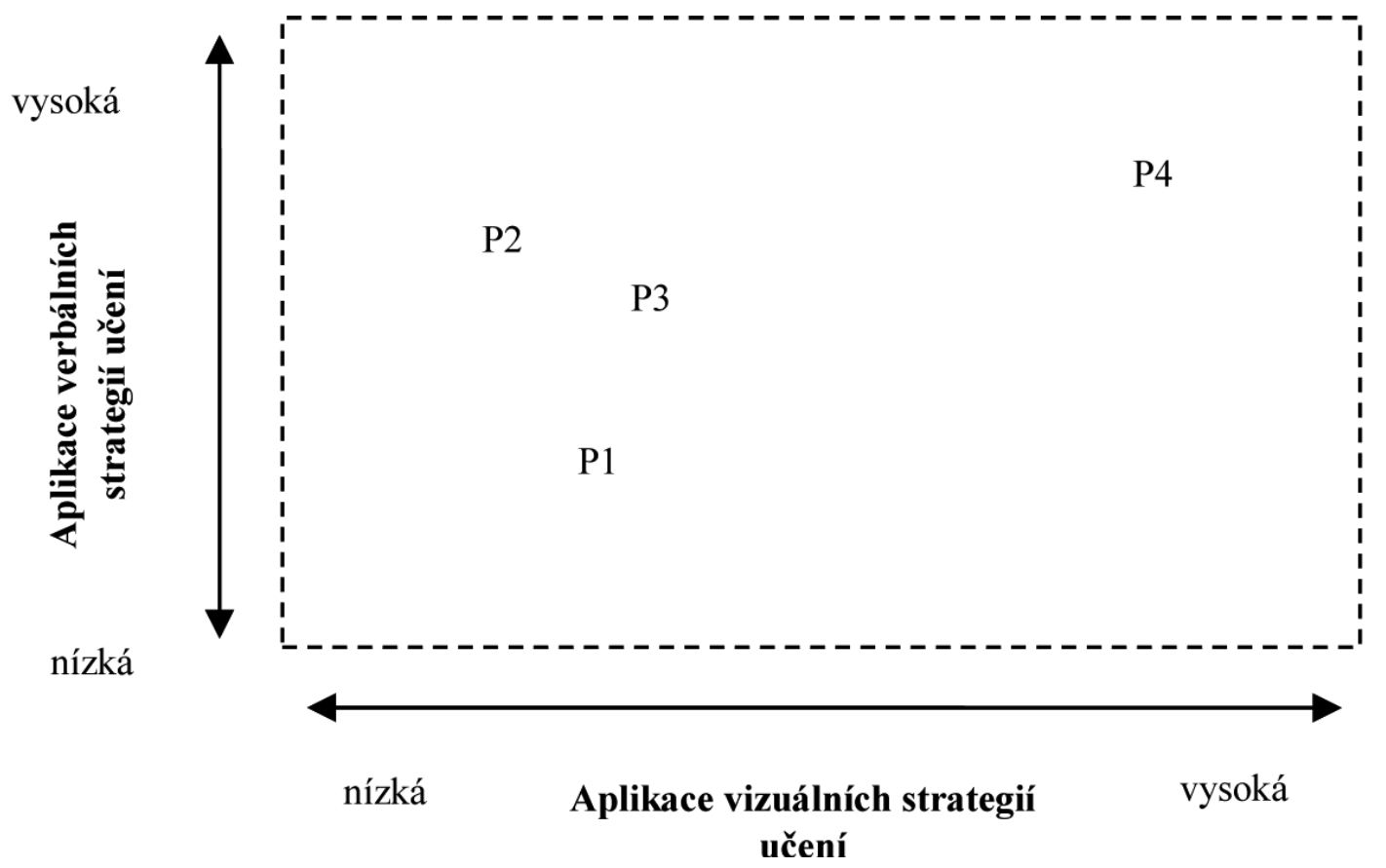

Obrázek 5. Poziční mapa - učební styly žáků (zpracování vlastní). 
Prostřednictvím tohoto analytického postupu lze např. zachytit i stěžejní rozdíly v případě chování žáků či jejich postoje $\mathrm{k}$ vyučujícím, výukovým strategiím a mnoha dalším aspektům edukační reality. V českém pedagogickém výzkumu byl prozatím problém různorodých významových vzorců v kvalitativních datech nejčastěji řešen používáním rozmanitých typologií (viz např. Rabušicová, Kamanová, \& Pevná, 2015). Ty sice zachycují ideální typy informantů či jejich jednání nebo významy, nicméně disponují dvěma metodologickými nedostatky. $V$ prvé řadě jsou často konstruovány intuitivně na základě zobecňování dat a velmi závisejí na výzkumníkově umu a na interpretativní imaginaci. $\mathrm{V}$ druhé řadě homogenizují výsledky do několika málo ideálních typů, které však nejsou reálnými pozicemi zastávanými informanty, ale jejich teoretickými abstrakcemi. ${ }^{8}$ Poziční analýza oproti tomu dbá na uchování relační povahy významových pozic, jejich korespondenci se získanými daty a na systematický způsob jejich vytváření skrze stanovení významových os.

\section{Závěr}

Metodologické debaty v kvalitativním výzkumu v první dekádě 21 . století přinesly celou řadu podnětných inovací, které jednoznačně reprezentuje i situační analýza. $V$ návaznosti na tyto debaty zde předložená studie usiluje o pozvání do situační analýzy jako specifického „balíku teorie/metody“, který je vhodným východiskem a nástrojem kvalitativně orientovaného pedagogického zkoumání. Situační analýza umožňuje nejenom vypořádat se s podstatnou částí kritiky, kterou přinesly epistemologické obraty 20 . století, ale také rozšírit paletu př́stupů a výzkumných technik, které lze ke zkoumání pedagogických jevů použít.

Zde předložená studie rozhodně neargumentuje v tom smyslu, že by situační analýza byla jedinou legitimní metodou kvalitativního zkoumání či nejlepší ze všech variant zakotvené teorie. Chápe ji jako jednu z mnoha cest porozumění významům, které jsou spojeny s edukační realitou, jejíž pozitiva vystoupí zvláště zřetelně, vezmeme-li v potaz její neodmyslitelný důraz na situaci - tzn. situaci jako neredukovatelný komplex elementů, které se vzájemně konstituují a jsou společně provázány, situaci, v níž se nacházejí osoby, jež

Ve vztahu k řešené problematice je velmi zajímavá stat' K. Šed’ové (2015) z loňského roku. Byt' se neodvolává na postupy situační analýzy, jako jeden ze svých hlavních výsledků de facto prezentuje poziční mapu moci ve školní třídě, která je výsledkem určení os: (1) míry sdílení definice situace žáky a vyučujícími a (2) míry centralizace moci ve tř́́dě. 
zkoumáme, a zároveň také situaci, do níž vstupuje výzkumník a svou přítomností se stává její součástí. Právě tyto charakteristiky z ní činí velmi vhodný výzkumný nástroj k porozumění edukačním mikrojevům.

K intenzivnímu užívání ji pak predisponují nejenom široká a inkluzivní epistemologicko-ontologická východiska, ale také zcela jedinečný přístup k předmětu bádání, $\mathrm{k}$ jehož exploraci slouží trojice výzkumných nástrojů. Ty umožňují zachytit nejenom výpovědi informantů, ale také materiální a diskursivní elementy situace a sledovat např. vztah žáků, studentů, učitelů a jiných aktérů k jejich vztažným skupinám a tématům, které jsou součástí diskursů, jež je obklopují, případně jejich pozice v těchto diskusích či ve vztahu k dalším elementům, jež jsou součástí situace.

Přestože jsme v úvodu reflektovali, že situační analýza je prozatím nevyužitou metodologickou př́ležitostí pedagogického výzkumu, pevně doufáme, že během následující dekády „zdomácní“ a dočkáme se celé řady prací, jež jí budou inspirovány. Takovýto přístup může přispět k smazávání rozdílů mezi metodologickými postupy používanými pedagogikou a dalšími společenskými vědami, respektive tuzemským a zahraničním zkoumáním.

\section{Literatura}

Blumer, H. (1969). Symbolic interactionism: Perspective and method. Englewood Cliffs: Prentice Hall.

Bodláková, L. (2012). Budování kariéry mladých žen v kontextu mateřské dovolené. Studia paedagogica, 17(2), 127-137.

Bonnell, V. E., Hunt, L. A., \& Biernacki, R. (1999). Beyond the cultural turn: New directions in the study of society and culture. Berkeley: University of Californa Press.

Brücknerová, K. (2011). Paleta hodnoticích situací a hodnoticích přístupů k výtvarné výchově. Studia paedagogica, 16(2), 49-73.

Bryant, A. (2002). Re-grounding grounded theory. Journal of Information Technology, Theory and Application, 44(1), 25-42.

Bryant, A., \& Charmaz, K. (2007). Grounded theory in historical perspective: An epistemological account. In A. Bryant \& K. Charmaz (Eds.), Handbook of grounded theory (s. 31-57). London: Sage.

Clarke, A. E. (2003). Situational analysis. Grounded theory after the postmodern turn. Symbolic Interaction, 26(4), 553-576.

Clarke, A. E. (2005). Situational analysis. Grounded theory after the postmodern turn. Thousand Oaks: Sage.

Clarke, A. E. (2009). From grounded theory to situational analysis. What is new? Why? How? In J. M. Moorse (Ed.), Developing grounded theory: The second generation (s. 194-233). Walnut Creek: Left Coast Press. 
Clarke, A. E. (2014). Grounded theory: Critiques, debates, and situational analysis. In A. E. Clarke \& K. Charmaz (Eds.), Grounded theory and situational analysis: History, essentials and debates in grounded theory. Thousand Oaks: Sage.

Clarke, A. E., Friese, C., \& Washburn, R. (Eds.). (2015). Situational analysis in practice. Mapping research with grounded theory. London: Left Coast Press.

Clarke, A. E., Friese, C., \& Washburn, R. (Eds.). (2016). Situational analysis: Grounded theory after the interpretative turn. London: Left Coast Press.

Creswell, J. W. (2014). Research design: Qualitative, quantitative and mixed methods approaches. Thousand Oaks: Sage.

Clarke, A. E., \& Charmaz, K. (2014). Editors' introduction: Grounded theory and situational analysis. In A. E. Clarke \& K. Charmaz (Eds.), Grounded theory and situational analysis: History, essentials and debates in grounded theory (s. 21-32). Thousand Oaks: Sage.

den Outer, B., Handley, K., \& Price, M. (2013). Situational analysis and mapping for use in education research: A reflexive methodology? Studies in Higher Education, 38(10), 1504-1521.

Denzin, N. K. (2007). Grounded theory and the politics of interpretation. In A. Bryant \& K. Charmaz (Eds.), The Sage handbook of grounded theory (s. 454-472). London: Sage.

Denzin, N. K., \& Lincoln, Y. S. (2005). The Sage handbook of qualitative research. Thousand Oaks: Sage.

Dey, I. (1999). Grounding grounded theory: Guidelines for qualitative inquiry. San Diego: Academic Press.

Ferdmanová, J. (2015). Typologie výukových strategií podporující inkluzi ve vzdělávání. Studia paedagogica, 20(3), 131-144.

Fosket, J. R. (2015). Situating knowledge. In A. E. Clarke, C. Friese, \& R. Washburn (Eds.), Situational analysis in practice. Mapping research with grounded theory (s. 195-215). London: Left Coast Press.

Foucault, M. (2000). Dozerat' a trestat'. Zrod väzenia. Bratislava: Kaligram.

Gavora, P. (2010). Úvod do pedagogického výzkumu. Brno: Paido.

Glaser, B. G., \& Strauss, A. L. (1967). The discovery of grounded theory: Strategies for qualitative research. Hawthorne: Aldine.

Gordon, T., Holland, J., \& Lahelma, E. (2001). Etnographic research in educational settings. In P. Atkinson, A. Coffey, S. Delamont, J. Lofland, \& L. H Lofland (Eds.), Handbook of etnography (s. 188-203). London: Sage.

Haig, B. D. (1995). Grounded theory as scientific method. Philosophy of Education, 28(1), 1-11.

Hallberg, L. R. (2006). The "core category" of grounded theory: Making constant comparisons. International Journal of Qualitative Studies on Health and Well-being, 1(3), 141-148.

Harris, G. (2011). Teacher educators under surveillance at a religious university. Teachers and Teaching: Theory and Practice, 17(5), 545-558.

Hlad'o, P. (2010). Dynamika rozhodování žáků základních škol o další vzdělávací dráze. Studia paedagogica, 15(2), 87-104.

Hood, J. C. (2007). Orthodoxy vs. power: The defining traits of grounded theory. In A. Bryant \& K. Charmaz (Eds.), The Sage handbook of grounded theory (s. 151-164). London: Sage.

Charmaz, K. (2000). Grounded theory: Objectivist and constructivist methods. In N. K. Denzin \& Y. S. Lincoln (Eds.), Handbook of qualitative research (s. 507-536). Thousand Oaks: Sage. 
Charmaz, K. (2006). Constructing grounded theory. London: Sage.

James, W., \& Mills, D. (2005). Introduction: From representation to action in the flow of time. In W. James \& D. Mills (Eds.), The qualities of time: Anthropological approaches (s. 1-15). Oxford: Berg.

Kalenda, J., \& Vávrová, S. (2015). Mapping the self-regulated learning of adults. In I. Krejčí, M. Flégl, \& M. Houška (Eds.), Efficiency and responsibility in education 2015. 12th international conference (s. 239-249). Dostupné z http://erie.pef.czu.cz/2015/Documents/ERIE2015_ electronical_complete.pdf

Kalenda, J., \& Vávrová, S. (2016). Self-regulated learning in students of helping professions. Procedia-Social and Behavioral Sciences, 217, 282-292.

Kalenda, J., \& Vávrová, S. (v tisku). Řízení učení běžných a netradičních studentů v terciárním vzdělávání: srovnávací situační analýza. In M. Dopita (Ed.), Netradiční studenti v terciárním vzdělávání. Olomouc: UP Olomouc.

Kelle, U. (2007). Development of categories: Different approaches in grounded theory. In A. Bryant \& K. Charmaz (Eds.), The Sage handbook of grounded theory (s. 191-213). Thousand Oaks: Sage.

Latour, B. (2005). Reassembling the social. An introduction to actor-network theory. Oxford: Oxford University Press.

Layder, D. (1998). Sociological practice: Linking theory and social research. London: Sage.

Makovská, Z. (2011). Techniky změny chování a jejich využití ze strany žáků. Pedagogická orientace, 21(1), 85-103.

Mertens, D. M. (2015). Research and evaluation in education and psychology. Integrating diversity with quantitative, qualitative and mixed methods. London: Sage.

Morse, J. M., Stern, P. N., Corbin, J., Bowers, B., Charmaz, K., \& Clarke, A. E. (Eds.). (2009). Developing grounded theory: The second generation. Walnut Creek: Left Coast Press.

Outhwaite, W., \& Turner, S. P. (Eds.). (2007). Handbook of social science methodology. Thousand Oaks: Sage.

Pol, M., Hloušková, L., Novotný, P., \& Sedláček, M. (2009). Úvodní fáze profesní kariéry ředitelů základních škol. Studia paedagogica, 14(1), 109-126.

Pol, M., Hloušková, L., Novotný, P., \& Sedláček, M. (2010). Profesní dráha ředitelů základních škol: od fáze profesní jistoty k novým výzvám. Studia paedagogica, 15(1), 85-105.

Prus, R. C. (1996). Symbolic interaction and etnographic research: Intersubjectivty and the study of human lived experience. Albany: State University of New York Press.

Rabušicová, M., Kamanová, L., \& Pevná, K. (2015). Učit se stárnout aktivně: senioři v mobilních počítačových učebnách. Studia paedagogica, 20(1), 85-108.

Redman-MacLaren, M., \& Mills, J. (2015). Transformational grounded theory: Theory, voice, and action. International Journal of Qualitative Methods, 14(3), 1-12.

Reichertz, J. (2007). Abduction: The logic of discovery of grounded theory. In A. Bryant \& K. Charmaz (Eds.), The Sage handbook of grounded theory (s. 214-228). London: Sage.

Rißler, G., Bossen, A., \& Blasse, N. (2014). School as space: Spatial alterations, teaching, social motives, and practice. Studia paedagogica, 19(4), 145-160.

Richardson, L. (1994). Writing: A method of inquiry. In N. K. Denzin \& Y. S. Lincoln. (Eds.), Handbook of qualitative research (s. 77-84). Greenwich: JAI.

Sedláčková, J. (2015). Typologie rodinných vypravěčů. Studia paedagogica, 20(3), 145-159. 
Simonová, J. (2015). Postoje rodičů k volbě základní školy. Studia paedagogica, 20(3), 69-87.

Strauss, A. L. (1984). Social worlds and their segmentation processes. Studies in Symbolic Interaction, 5, 123-139.

Strauss, A. L., \& Corbin, J. (1990). The basics of qualitative analysis: Grounded theory procedures and techniques. Thousand Oaks: Sage.

Strauss, A. L., \& Corbin, J. (1998). The basics of qualitative analysis: Grounded theory procedures and techniques. Thousand Oaks: Sage.

Strauss, A. L., \& Corbin, J. (1999). Základy kvalitativního výzkumu: postupy a techniky metody zakotvené teorie. Boskovice: Albert.

Suddaby, R. (2006). What grounded theory is not. Academy of Management Journal, 49(4), 633-642.

Šed'ová, K. (2005). Možnosti uplatnění zakotvené teorie v pedagogickém výzkumu: rodinná socializace dětského televizního diváctví. Studia paedagogica, 10(1), 123-132.

Šed'ová, K. (2006). Mediální výchova v rodinách předškoláků. Pedagogická orientace, 16(1), 72-85.

Šed'ová, K. (2009). Tiché partnerství: vztahy mezi rodiči a učitelkami na prvním stupni základní školy. Studia paedagogica, 14(1), 27-51.

Šed'ová, K. (2015). Moc v dialogickém vyučování. Pedagogická orientace, 25(1), 32-62.

Šíp, R. (2015). Pedagogika a paradigmatický obrat v metodologii a teorii. Pedagogická orientace, 25(5), 671-699.

Švaříček, R. (2006). Rozvíjející se kvalitativní přístupy ke zkoumání edukační reality. Aula, 14(4), 22-30.

Švaříček, R., Šed’ová, K., Sedláček, M., Novotný, P., Nedbálková, K., Miková, M., ... Zounek, J. (2007). Kvalitativní výzkum v pedagogických vědách. Praha: Portál.

Thomas, G., \& James, D. (2006). Reinventing grounded theory: Some questions about theory, ground and discovery. British Educational Research Journal, 32(6), 767-795.

Titscher, S., Meyer, M., Vetter, E., \& Wodak, R. (2000). Methods of text and discourse analysis. London: Sage.

Wacquant, L. (2002). Scrutinizing the street: Poverty, morality, and the pitfalls of urban ethnography. American Journal of Sociology, 107(6), 1648-1532.

Wiegerová, A., \& Gavora, P. (2014). Proč se chci stát učitelkou v mateřské škole? Pohled kvalitativního výzkumu. Pedagogická orientace, 24(4), 510-534.

Wortham, S., \& Jackson, K. (2008). Educational constructionisms. In J. F. Gubrium \& J. A. Holstein (Eds.), Handbook of constructionist research (s. 107-127). New York: Guilford Press.

Yin, R. K. (2002). Case study research. Design and methods. Thousand Oaks: Sage.

\section{Autor}

Mgr. Jan Kalenda, Ph.D., Univerzita Tomáše Bati ve Zlíně, Fakulta humanitních studií, Centrum výzkumu, Mostní 5139, 76001 Zlín, e-mail: kalenda@fhs.utb.cz 


\title{
A new opportunity: Situational analysis in educational research
}

\begin{abstract}
The present study deals with the possibilities of utilizing situational analysis in pedagogical research. Although situational analysis is a new method that has been significantly developing only in the last decade, it is now widely used in a range of social sciences and humanities. Despite the success across various disciplines, situational analysis has not yet widely penetrated into the research on education neither abroad, nor in the Czech Republic. It is still dominated by the first generation grounded theory or the constructivist oriented grounded theory. The present study responds to this deficit by representing situational analysis as a "theory/method package" while demonstrating not only its ontological-epistemological bases for the study of social/educational reality and the main differences from the classic grounded theory, but also principles for using the three key tools of situational analysis: (1) situational maps, (2) maps of social worlds and arenas and (3) positional maps. The study demonstrates the use of all these three tools for examining various aspects of education. In a discussion on these aspects, the study highlights the key benefits of situational analysis as a theoretical-methodological approach to the study of educational phenomena.
\end{abstract}

Keywords: situational analysis, grounded theory, qualitative research, methodology of educational research

Janík, T., Minaříková, E., Píšová, M., Uličná, K., \& Janík, M. (2015). Profesní vidění učitelů a jeho rozvíjení prostřednictvím videoklubů. Brno: Masarykova univerzita.

Tato kniha je o přivádění viděného k řeči. Je také o profesi a profesionalitě. Autoři popisují nejen povahu profesního vidění učitelů anglického jazyka, ale i to, jak se změnilo po účasti ve videoklubech. Kniha je př́íspěvkem k diskusi o profesním vidění jako součásti učitelské profesionality a o možnostech využití profesních učících se komunit a videosekvencí výuky ve vzdělávání učitelů. 